\title{
Plasma Insulin Studies in Patients with Lag Curves
}

\author{
M.T. McKindiE*, R.T.A. ScotT** and K.D. BuchanaN*** \\ With the technical assistance of I.A. Huntar, Royal Infirmary, Glasgow
}

Received: May 19, 1969

Summary. The significance of the lag curve, i.e. one in which the blood sugar rises rapidly from a normal fasting value to more than $180 \mathrm{mg} / 100 \mathrm{ml}$ but returns to the fasting value within $120 \mathrm{~min}$, remains controversial. In order to study this further, plasma insulin levels were measured by immunoassay during oral and intravenous glucose tolerance tests in 3 groups of age/weight matched subjects: Group 1, 14 with unexplained lag curves: Group 2,14 with lag curves following gastric surgery and Group 3,14 normal subjects. The mean insulin levels were higher in Group 1 than in Group 3 but the hyperglycaemic stimu. lus was greater. The insulin response in Group 2 did not differ significantly from the controls. The mean blood sugar curves were similar in Groups 1. and 2, but despite this the insulin response was significantly prolonged in Group 1, suggesting a degree of insulin resistance or antagonism. In the intravenous test 2 patients from each of Groups 1 and 2 had a $K$ value in the diabetic range. The mean $K$ value was higher in Group 1 than in Group 2 . Both groups showed a similar rather low insulin response,

Etude de l'insuline plasmatique chez des patients présentant un pic élevé dans leur courbe

Résumé. La signification de la courbe pointue («agcurve») c-à-d celle dans laquelle le sucre sanguin monte rapidement à partir de la valeur normale à jeun à plus de $180 \mathrm{mg} / 100 \mathrm{ml}$ mais retourne à la valeur à jeun en $120 \mathrm{~min}$, reste controversée. Pour étudier cela plus profondément, le taux de l'insuline plasmatique a été mesuré par dosage radio-immunologique, pendant des épreuves de tolérance au glucose orales et intraveineuses, chez trois groupes de sujets comparables en ce qui concerne l'âge et le poids. Groupe 1, 14 avec des courbes pointues inexpliquées [(lagstorage curves) caractéristique de l'absorption intestinale rapide]. Groupe 2, 14 avec des courbes pointues à la suite d'une intervention chirurgicale gastrique. Groupe 3, 14 sujets normaux. Le taux moyen d'insuline était plus élevé dans le groupe 1 que dans le groupe 3, mais le stimulus hyperglycémique était plus grand. La réponse insulinique dans le groupe 2 n'a pas differé des témoins d'une façon significative. La courbe moyenne du sucre sanguin était semblable dans les groupes 1 et 2 , mais en dépit de ceci, la réponse insulinique était significativement prolongée dans le groupe 1 suggérant un degré de résistance ou d'antagonisme insulinique. Dans les épreuves intravoineuses, 2 malades de chacun des groupes 1 et 2 avaient une valeur $\mathrm{K}$ dans le domaine des valeurs diabétiques. La valeur moyenne de $K$ était plus élevée dans le groupe 1 que dans le groupe 2. Les deux groupes montraient une réponse insulinique semblable mais plutôt basse.

Plasmainsulin-Untersuchungen bei Patienten mit spitzgipfligen Glucose-Toleranz-Kurven

Zusammenfassung. Dio Bedeutung von spitzgipfligen Blutzuckerkurven, die von normalen Nüchternspiegeln auf mehr als $180 \mathrm{mg} \%$ ansteigen, um in $120 \mathrm{~min}$ auf die Ausgangswerte zurückzukehren, bleibt strittig. - Um diese Frage weiter zu klären, wurden immunologisch die Plasma-Insulinwerte bei 3 Gruppen von je 14 Probanden gemessen, die nach Alter und Gewicht übereinstimmten: Gruppe 1 bestand aus Probanden mit derartigen Kurven ohne ausreichende Erklärung, Gruppe 2 aus Patienten nach Magenoperationen und Gruppe 3 diente als Vergleichskollektiv. Im Teilkollektiv 1 fanden sich höhere Insulinwerte als in 3, doch bestand gleichzeitig eine stärkere Blutzuckererhöhung als Stimulans. Die Insulinausschüttung in der Gruppe 2 unterschied sich nicht signifikant vom Vergleichskollektiv. In den Gruppen 1 und 2 stimmen die Blutzuckerspiegel weitgehend überein, doch hielt die Erhöhung der Insulinkonzentration in Gruppe 1 signifikant länger an, was auf einen gewissen Grad von Insulin-Resistenz oder -Antagonismus schließen läßt. Bei der i.v. Belastung ergaben sich für je 2 Probanden der Gruppen 1 und $2 k$-Werte im diabetischen Bereich. In Gruppe 1 lagen die mittleren $k$-Werte höher als in Gruppe 2. Beide Teilkollektive zeigten eine eher erniedrigte Insulin-Ausschüttung.

Key-words: Plasma insulin, glucose tolerance test, postgastrectomy, carbohydrate metabolism, lag curves.

\section{Introduction}

Glucose tolerance tests have been used in the detection of diabetes mellitus for many years but their interpretation and the definition of normality are controversial (Butterfield, 1964; Keen, 1964; Sharp, 1964). Subjects with normal glucose tolerance and those with frank symptomatic diabetes form two extremes. Between lie a large number of people who have minor abnormalities of glucose tolerance. One such abnormality is the 'lag' curve in which the blood sugar rises

\footnotetext{
* Present address: Maryfield Hospital, Dundee.

** Present address: Southern General Hospital, Glasgow.

**** Present address: Royal Victoria Hospital, Belfast.
}

rapidly from a normal fasting value to a peak of more than $180 \mathrm{mg} / 100 \mathrm{ml}$ but, unlike the diabetic curve, returns to the fasting value by $120 \mathrm{~min}$. This is regarded by some workers as a prelude to frank diabetes (Lundbaek, 1962), although the mechanism is ill-understood. Even patients who have a lag curve following partial gastric resection, presumably due to more rapid absorption of glucose, may show an increased tendency to develop diabetes (Berkowitz and Glassman, 1966; Tobe et al., 1967).

The introduction of a reliable immunoassay method for insulin (Yalow and Berson, 1960) has added another parameter to the investigation of glucose tolerance, and may throw some light on the mechanism and significance of the 'lag' curve. 


\section{Materials and Methods}

Patients studied. Group 1. Twenty-seven patients, referred to the diabetic elinic at Glasgow Royal Infirmary because of glycosuria detected at a routine medical examination, were discovered to have a lag curve. A number of these patients were overweight and in a few others the height had not been recorded so that percentage weight could not be calculated. Of the remainder, 14 were selected to form age/weight matched pairs with the patients in Group 2.

Group 2. Fourteen patients had lag curves following partial gastrectomy or vagotomy and drainage. A number of these had also been referred because of glycosuria, the remainder were being investigated for post-gastrectomy symptoms.

Group 3. Fourteen normal subjects, aged 31-65 years, mean 48 and of weights $84-113$ per cent of ideal, mean 99 , were studied as a control group. tolerance tests (IVGTT) were performed according to the method of Lundbaek (1962), blood being taken fasting and at $10 \mathrm{~min}$ intervals for one hour following the intravenous injection of $25 \mathrm{~g}$ of glucose as a $50 \%$ solution. All subjects were instructed to eat a normal diet for at least 3 days prior to the tests.

Plasma insulin was assayed according to the immuno-precipitation technique of Hales and Randle (1963). Standards and antisera are as described elsewhere (Buchanan and McKiddie, 1967a). Blood sugars were estimated as total reducing substances using a Technicon autoanalyser.

\section{Results}

\section{Oral glucose tolerance tests}

The plasma insulin response to oral glucose in the 27 patients in Group 1 is shown in Table 1. Eight patients had at least one plasma insulin value outside

\begin{tabular}{|c|c|c|c|c|c|c|c|c|}
\hline \multirow[b]{2}{*}{ Subject } & \multirow[b]{2}{*}{ Age yrs. } & \multirow[b]{2}{*}{$\begin{array}{l}\text { Weight } \\
\%\end{array}$} & \multicolumn{5}{|c|}{$\begin{array}{l}\text { Minutes after oral glucose } \\
\text { Plasma insulin } \mu \text {-units } / \mathrm{ml}\end{array}$} & \multirow[b]{2}{*}{120} \\
\hline & & & & 0 & 30 & 60 & 90 & \\
\hline 1 & 51 & - & & 50 & 190 & 174 & 85 & 46 \\
\hline 2 & 47 & - & & 9 & 22 & 67 & 82 & 10 \\
\hline 3 & 43 & - & & 27 & 49 & 60 & 81 & 64 \\
\hline 4 & 60 & - & & 2 & 55 & 75 & 40 & 18 \\
\hline 5 & 37 & 113 & & 21 & 81 & 72 & 99 & 51 \\
\hline 6 & 72 & 146 & & 70 & 158 & 205 & 136 & 69 \\
\hline 7 & 61 & 153 & & 51 & 102 & 186 & 208 & 111 \\
\hline 8 & 57 & 120 & & 46 & 165 & 180 & 83 & 45 \\
\hline 9 & 55 & 147 & & 42 & 90 & 140 & 67 & 50 \\
\hline 10 & 33 & 114 & & 33 & 58 & 49 & 41 & 29 \\
\hline 11 & 42 & 110 & & 46 & 162 & 78 & 69 & 60 \\
\hline 12 & 58 & 147 & & 52 & 135 & 119 & 100 & 70 \\
\hline 13 & 40 & 98 & & 32 & 82 & 118 & 28 & 38 \\
\hline 14 & 39 & 117 & & 35 & 48 & 75 & 52 & 37 \\
\hline 15 & 43 & 95 & & 0 & 93 & 49 & 12 & 11 \\
\hline 16 & 41 & 88 & & 12 & 47 & 41 & 31 & 18 \\
\hline 17 & 38 & 99 & & 18 & 80 & 91 & 53 & 30 \\
\hline 18 & 50 & 100 & & 32 & 153 & 151 & 56 & 26 \\
\hline 19 & 64 & 98 & & 27 & 97 & 193 & 173 & 87 \\
\hline 20 & 40 & 100 & & 30 & 190 & 70 & 35 & 30 \\
\hline 21 & 47 & 108 & & 20 & 53 & 71 & 53 & 31 \\
\hline 22 & 31 & 100 & & 35 & 91 & 81 & 118 & 51 \\
\hline 23 & 71 & 100 & & 22 & 86 & 139 & - & 53 \\
\hline 24 & 63 & 82 & & 41 & 81 & 260 & 223 & 129 \\
\hline 25 & 56 & 116 & & 80 & 183 & 171 & 96 & 84 \\
\hline 26 & 52 & 80 & & 32 & 220 & 245 & 195 & 41 \\
\hline 27 & 34 & 100 & & 20 & 210 & 112 & - & 84 \\
\hline \multicolumn{9}{|l|}{ Mean } \\
\hline$(14-27)$ & 48 & 98 & & 29 & 117 & 125 & 91 & 51 \\
\hline \multirow{3}{*}{ Controls } & 48 & 99 & & 18 & 86 & 99 & 53 & 26 \\
\hline & & & $P$ & NS & NS & NS & NS & 0.05 \\
\hline & & & \multicolumn{6}{|c|}{ Blood sugar $\mathrm{mg} / 100 \mathrm{ml}$} \\
\hline \multirow{3}{*}{\multicolumn{3}{|c|}{$\begin{array}{l}\text { Mean (Patients 14-27) } \\
\text { Controls }\end{array}$}} & & 97 & 192 & 172 & 106 & 78 \\
\hline & & & & 94 & 137 & 121 & 92 & 79 \\
\hline & & & $P$ & NS & 0.001 & 0.01 & NS & NS \\
\hline
\end{tabular}

Test procedure. Standard oral glucose tolerance tests (GTT) were performed, venous bloods being taken fasting and at 30,60, 90 and 120 min after $50 \mathrm{~g}$ oral glucose. In a number of patients intravenous glucose our normal range (Buchanan and MoKiddie, 1967b), but 4 of these 8 were also obese. Fourteen of the patients, all within $20 \%$ of ideal weight (Nos. 14-27 in Table 1) were compared with the 14 normal subjects 
of Group 3 who formed age/weight matched pairs. The mean plasma insulin levels were higher throughout in the lag curve group, and the response tended to be more prolonged. However, because of the wide scatter of results the difference was significant only at $120 \mathrm{~min}$.

As might be expected the 30 and $60 \mathrm{~min}$ blood sugar values were significantly higher in the lag curve group. The fasting and 120 min levels were virtually identical.

The insulin response to oral glucose of the $14 \mathrm{pa}$ tients whose lag curve followed gastric surgery is shown in Table 2. Three of these patients had one plasma insulin level outside our normal range. There was no significant difference between the mean plasma insulin levels of these patients and those of the normal controls. The mean peak insulin response in the ulcer patients appeared considerably higher than in the controls $(136 \pm 84: 86 \pm 50)$, but again because of the wide scatter statistical significance was not achieved $(p<0.10)$. The mean blood sugar values were again significantly higher at 30 and $60 \mathrm{~min}$ in the Group 2 patients than in the controls.

There are inherent difficulties in comparing plasma insulin responses in patients with widely different

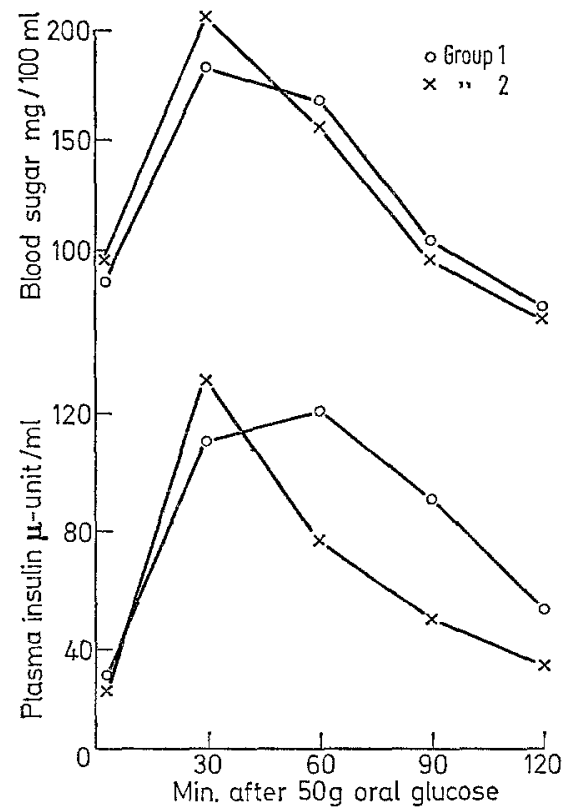

Fig. 1. The mean blood sugar and plasma insulin responses to oral glucose of Group 1 (idiopathic lag curves) are compared with those of Group 2 (post-gastrectomy lag curves)

Table 2. Insulin response to glucose in patients with lag curves following gastric surgery. Comparison with means of 14 age/weight matched normal subjects

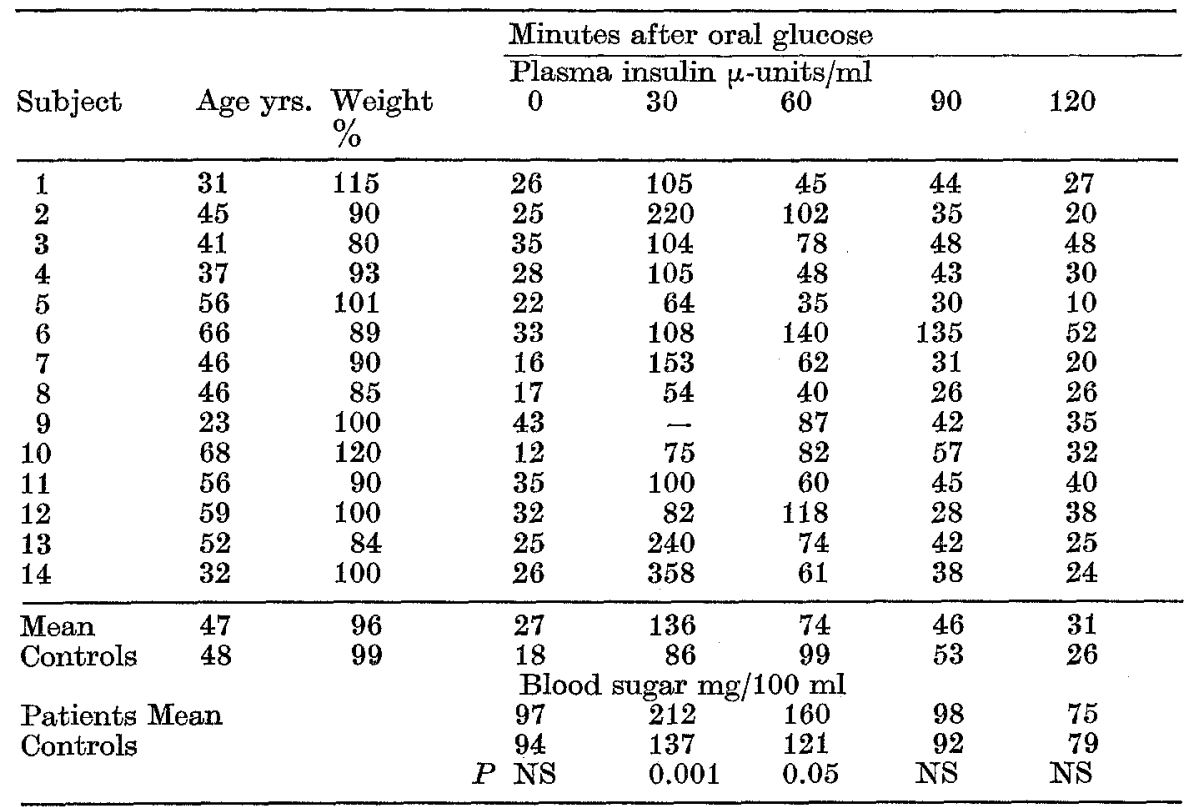

blood sugar values. However, when the mean blood sugar values of the two groups of patients with lag curves were compared they were closely similar. Therefore in this respect these two groups are directly comparable. The fasting plasma insulin level was similar in the two groups. The peak insulin response occurred in both groups at $30 \mathrm{~min}$ and was slightly, though not significantly, higher in the 'post-gastrectomy' group. Thereafter the insulin levels fell rapidly in the latter, whereas they remained elevated for longer in the patients of Group 1, who therefore had significantly higher insulin levels at 60,90 and $120 \mathrm{~min}$.

\section{Intravenous glucose tolerance tests}

In order to overcome the problem of variable absorption of oral glucose intravenous glucose tolerance tests were performed in 9 patients from Group 1, 6 patients from Group 2 and 6 of the control group. Two 
patients from each of Groups 1 and 2 had a glucose disappearance rate ( $K$ value) in the diabetic range $(<0.95)$. A further 2 patients in Group 2 had a borderline $K$ value $(0.95-1.05)$. The mean $K$ value of the patients in Group 1 (1.53) was higher than that of patients in Group 2 (1.02) $(p<0.05)$.

The mean insulin response to intravenous glucose was similar in both lag curve groups (Table 3) and rather lower than in the normal subjects studied. to insulin and this may well be an early manifestation of diabetes. From our data of normal oral glucose tolerance (Buchanan and McKiddie, 1967b) we have shown positive correlations between the sugar and insulin responses only at 90 and $120 \mathrm{~min}$ after oral glucose, so that higher insulin levels at this latter part of the oral GTT may be consistent with decreased effectiveness of circulating insulin. The factors governing the insulin response to oral and intravenous glucose

Table 3. Plasma insulin response to $1 . V$. glucose means \pm 1 standard deviation

\begin{tabular}{|c|c|c|c|c|c|c|c|c|}
\hline & \multirow[b]{2}{*}{$K$} & \multicolumn{7}{|c|}{$\begin{array}{l}\text { Minutes after } 25 \mathrm{~g} \text { glucose I.V. } \\
\text { Plasma insulin } \mu \text {-units } / \mathrm{ml}\end{array}$} \\
\hline & & 0 & 10 & 20 & $\mathbf{3 0}$ & 40 & 50 & 60 \\
\hline Group 1. (9) & 1.53 & $14 \pm 9$ & $42 \pm 18^{a}$ & $38 \pm 15$ & $40 \pm 21$ & $44 \pm 17$ & $42 \pm 14$ & $42 \pm 16$ \\
\hline Group 2. (7) & 1.02 & $20 \pm 5$ & $35 \pm 16^{\mathrm{a}}$ & $39 \pm 9$ & $39 \pm 14$ & $34 \div 14$ & $44 \pm 4$ & $46 \pm 10$ \\
\hline Group 3. (6) & 2.22 & $34 \pm 12$ & $80 \pm 31^{a}$ & $71 \pm 37$ & $49 \pm 19$ & 46 土18 & $37 \pm 21$ & $32 \pm 20$ \\
\hline
\end{tabular}

a Significance of difference between Groups 1 and 2 and normals $p<0.02$.

\section{Discussion}

The mechanism of the lag curve is poorly understood. In post-gastrectomy patients the obvious explanation is the more rapid passage of glucose into the jejunum and thence into the blood stream, although Samols et al. (1966) have also implicated increased. levels of plasma glucagon. Whether a similar mechanism is responsible in non-surgical cases, or whether it is the peripheral or hepatic disposal of glucose which is at fault is not known.

The finding of impaired tolerance to intravenous glucose is in favour of the latter being at least a factor. This delayed clearance of intravenous glucose has been shown previously both in surgical (Robertson, 1966) and non-surgical cases (Lundbaek, 1962), although not all workers are agreed (Schecter and Necheles, 1949). There is also doubt in the post-gastrectomy patients whether this abnormality follows or precedes surgery, an increased incidence of both lag curves and abnormal IVGTT having been reported in uncomplicated peptic ulcers (Platt etal., 1949), although our data in this respect (Buchanan et al., 1967) did not show evidence of either abnormal or IVGTT in subjects with duodenal ulcers.

It has been suggested (Berkowitz and Glassman, 1966) that a lag curve, at least in post-gastrectomy subjects, may be the cause rather than the result of a tendency to develop diabetes. The hyperglycaemia may cause excessive beta cell stimulation with secondary failure, just as perfusion of the pancreas with concentrated glucose solutions in animals has been shown to produce at least temporary diabetes (Dohan and Lukens, 1948; Barron and State, 1949). Support for this is given by the autopsy finding of vacuolization and decrease in beta cell granules in older post-gastrectomy patients (Tobe et al., 1967).

The finding of a prolonged higher insulin response, in the idiopathic lag curve group, suggests that these patients have some form of antagonism or resistance are different (MeIntyre et al., 1964). Various intestinal factors have been implicated in the increased insulin response seen after oral glucose as compared with intravenous glucose. These include secretin (Dupré et al., 1966) pancreozymin (Meade et al., 1967) glucagon (Samols et al., 1966) and gastrin (Unger et al., 1967). It might be that the lag curve is the result of an altered response of insulinogenic gut factors following a glucose load. The study of this possibility must await reliable assay methods for these hormones.

Acknowledgements. We are pleased to acknowledge the help and encouragement of Dr. A.H. Imrie and Professor E.M. MeGirr. We are grateful to the biochemistry department for performing the blood sugar estimation.

\section{References}

Barron, S.S., State, D.: Effect of prolonged intravenous administration of dextrose on B-cells of islets of Langerhans. Arch. Path. 48, 297-304 (1949).

Berkowitz, D., Glassman, S.: Carbohydrate metabolism in the subtotal gastrectomy patient. Amer. J. Gastroent. 46, 119-129 (1966).

Buchanan, K.D., MeKiddie, M.T.: Experience with the immuno-precipitation technique of insulin assay with reference to sensitivity, precision and specificity, Clin. chim. Acta 15, 315-320 (1967a).

- The normal insulin response to glucose. The relationship between blood sugar and plasma insulin. Diabetologia 3, 460-464 (1967).

- Lindsay, A.C., Manderson, W.G.: Carbohydrate metabolism in duodenal ulcer patients. Gut 8, 325-331 (1967).

Butterfield, W.J.H. : Summary of Results of the Bedford Diabetes Survey. Proc. roy. Soc. Med. 57, 196-200 (1964).

Dohan, F.C., Lukens, F.D.W.: Experimental diabetes produced by the administration of ghcose. Endocrinology 42, 244-262 (1948).

Dupré, J., Rojas, L., White, J.J., Unger, R.H., Beck, J.C.: Effects of secretin on insulin and glucagon in portal and peripheral blood in man. Lancet 1966 II, $26-27$.

Hales, C.N., Randle, P.J.: Immunoassay of insulin with insulin antibody precipitate. Biochem. J. 88, 137-146 (1963). 
Keen, H. : The Bedford survey : a critique of methods and findings. Proc. roy. Soc. Med. 57, 200-202 (1964).

Lundbaek, K. : Intravenous glucose tolerance as a tool in definition and diagnosis of diabetes mellitus. Brit. med. J. 1962 I, $1507-1513$.

MeIntyre, N., Holdsworth, C.D., Turner, D.S.: New interpretation of oral glucose tolerance. Lancet 1964 II, $20-21$.

Meade, R.C., Kneubuhler, H.A., Schulte, W.J., Barbomate, J.J.: Stimulation of insulin secretion by pancreozymin. Diabetes 16, 141-144 (1967).

Platt, W.D., Jr., Dotti, L.B., Beekman, R.S.: Glucose tolerance in patients with peptic ulcer. Gastroenterology 13, 20-30 (1949).

Robertson, P.D.: Carbohydrate intolerance in postgastrectomy patients. Arch. intern. Med. 117, 764 -768 (1966).

Samols, E., Tyler, J., Marks, V.: Immuno-reactive glucagons in human pancreas, gut and plasma. British Diabetic Association Meeting, London (1966).
Schecter, S.E., Necheles, H.: Postprandial symptoms following subtotal gastrectomy for peptic ulcer and their relationship to the glucose tolerance curve. Gastroenterology 12, 258-274 (1949).

Sharp, C.L.: Diabetes Survey in Bedford 1962. Proc. roy. Soc. Med. 57, $193-195$ (1964).

Tobe, T., Kouchi, M., Tanimura, H., Huang, C.H. : Hyperglycaemia after gastrectomy as a prediabetic state: clinical study of 100 post-gastrectomy patients. Arch. Surg. 94, 836-840 (1967).

Unger, R.H., Ketterer, H., Dupré, J., Eisentraut, A.M.: The effects of secretin pancreozymin and gastrin on insulin and glucagon secretion in anesthetised dogs. J. clin. Invest. 46, 630-645 (1967).

Yalow, R.S., Berson, S.A.: Immunoassay of endogenous plasma insulin in man. J. clin. Invest. 39, 1157-1175 (1960).

\section{Dr. M.T. McKiddie}

Medical Unit

Maryfield Hospital Dundee

Dundee, DD 47 TL, Great Britain 